INSIGHTS INTO REGIONAL DEVELOPMENT

ISSN 2669-0195 (online) http://jssidoi.org/IRD/

2020 Volume 2 Number 3 (September)

http://doi.org/10.9770/IRD.2020.2.3(4)

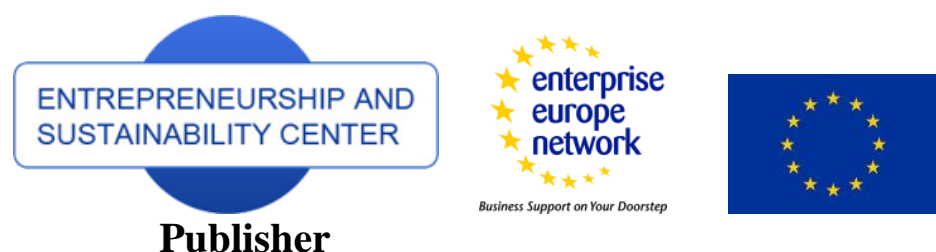

http://jssidoi.org/esc/home

\title{
CIRCULAR ECONOMY AND ECO-INNOVATION IN ITALIAN INDUSTRIAL CLUSTERS. BEST PRACTICES FROM PRATO TEXTILE CLUSTER*
}

\author{
Francesca Mazzoni \\ Department of Economics and Management, University of Ferrara, Via Voltapaletto 11, Ferrara 44121, Italy \\ Email: Francesc.mazzoni@student.unife.it
}

Received 22 April 2020; accepted 20 June 2020; published 30 September 2020

\begin{abstract}
The transition of Italian industrial clusters towards more circular and sustainable models of production could lead to substantial environmental, economic and societal benefits. The aim of this paper is to analyse which specific types of eco-innovations could lead to the implementation of circular economy in industrial clusters. The paper intends to do so not only performing a theoretical analysis but also exploring the case study of the Prato textile industrial cluster that, through the introduction of different circular and symbiotic measures has been able to significantly reduce its environmental impact and at the same time thrive and succeed.
\end{abstract}

Keywords: circular economy; eco-innovation; industrial symbiosis; industrial clusters

Reference to this paper should be made as follows: Mazzoni, F. 2020. Circular economy and eco-innovation in Italian industrial clusters. Best practices from Prato textile cluster. Insights into Regional Development, 2(3), 661-676. https://doi.org/10.9770/IRD.2020.2.3(4)

JEL Classifications: F02, L60, O32

\section{Introduction}

The world we live in is characterized by increasingly scarce natural resources, but in spite of that our consumeristic society still relies on a linear economic model of production and consumption, characterized by a simple 'take-make-dispose' approach, actively contributing to the depletion of the already limited natural resources and to environmental degradation. Circular economy arose as a sustainable and feasible alternative model to the linear one, which aims at regenerating itself relying less and less on raw materials, and which seems to have the potential to generate better outcomes on both environment, economy and society than the current development path (McKinsey \& Company 2016). Circular models of production and consumption can be applied at any level of economy -micro, meso and macro- and almost in any field. In particular, this study will address the meso level of circular economy, which mainly focuses on local ecosystems and industrial networks (Ghisellini et al. 2016). The choice of focusing on this specific level was taken because of the characteristics of Italian economy, which heavily relies on industrial clusters. According to ISTAT (2015), in fact, they represent about

\footnotetext{
* The publishing was supported by Entrepreneurship and Sustainability Center, Lithuania
} 


\section{INSIGHTS INTO REGIONAL DEVELOPMENT}

ISSN 2669-0195 (online) http://jssidoi.org/jesi/

2020 Volume 2 Number 3 (September)

http://doi.org/10.9770/IRD.2020.2.3(4)

one-fourth of Italian economic system, in term of LMAs, workers and local units. However, while industrial clusters play a pivotal role in driving economic development, they also exert a significant impact on natural ecosystems due to their intensive use of natural resources and waste they generate (Cariani 2010).

The idea at the basis of this study is that an overall and effective transition of Italian industrial clusters towards more circular and sustainable models could produce substantial environmental, economic and social benefits not only at a local level, but also at a broader national one, and that this transition could be achieved and accelerated through the implementation of circular economy-related eco-innovations within the clusters.

In order to evaluate the effective benefits that implementing circular economy-related eco-innovations at industrial clusters level could produce, this thesis intends to explore the successful case study of the Prato industrial cluster, which it has been chosen for 3 main reasons: a) Prato Industrial cluster was one of the first ones in Italy to introduce circular economy and sustainable strategies in its organization and business model; b) it is one of the most sustainable clusters in Italy, which is confirmed also by the several awards and recognitions obtained throughout its life; c) Prato industrial cluster is specialized in textile production, which is a relevant aspect since textile industry is one of the most polluting and resource depleting of the world, mainly in terms of water. Textile industry is, in fact, known to be a highly water intensive sector, it has been estimated that it uses 200-400 litres per $\mathrm{kg}$ of finished product, and consequently, it also generates large amounts of polluted wastewater (Buscio et al. 2019). Despite its wasteful nature, Prato textile cluster was able to thrive and at the same time substantially reduce its environmental impacts through the introduction of sustainable practices end circular economy-related eco-innovations, specially linked to wastewater management and recycle. In particular, it is important to understand which specific eco-innovations implemented in the cluster were actually able to spur circular economy and to make the cluster thrive and succeed. This analysis could constitute an important starting point for the replication of these circular economy-related eco-innovations in other industrial clusters, especially in textile ones, characterized by similar resource consumption patterns.

Thus, the research questions this paper aims at answering are:

Which kinds of eco-innovations could spur circular economy, specifically in industrial clusters? Are industrial clusters a suitable environment in which to introduce circular economy practices?

The paper will try to answer the research questions studying the subject both theoretically and practically, which means by making a careful analysis of previous literature and by investigating the real-life case study of the Prato textile industrial cluster.

The paper is organized as follows: the second section addresses the concept of circular economy. Its meaning, origins and levels are explored and deepened. In the third section the focus is on eco-innovation as a driver of circular economy. This section is aimed at clarifying the link between eco-innovation and circular economy and at explaining how a systemic eco-innovation, as industrial symbiosis, can contribute to the implementation of circular principles in industrial clusters. The fourth section focuses on Italian industrial clusters, with a particular emphasis on the textile ones and on their environmental impacts, as also on the emergence and diffusion of ecoindustrial clusters. In the fifth section, the focus is entirely on the Prato industrial cluster, the circular and resource efficient eco-innovations it has implemented and the obtained results. Finally, in the conclusions of the paper, we will try to answer our original research questions.

\section{An exploration of the concept of circular economy}

The concept of circular economy has gained momentum since the late 1970s (Ellen MacArthur Foundation 2013), but it's in the last years that it started attracting more and more attention from both scholars and practitioners from different fields. This seems to be indicated also by the rapid growth of peer-reviewed articles related to circular economy: 30 were published in 2014, compared to more than 100 in 2016 (Geissdoerfer et al. 2017). Despite 


\section{INSIGHTS INTO REGIONAL DEVELOPMENT}

ISSN 2669-0195 (online) http://jssidoi.org/jesi/

2020 Volume 2 Number 3 (September)

http://doi.org/10.9770/IRD.2020.2.3(4)

circular economy increasing importance, a common and unanimously accepted definition doesn't seem to exist yet. Kirchherr et al. (2017) identified and collected 114 different definitions from different peer-reviewed articles, policy papers and reports, further evidence that circular economy is still a blurred concept that means many different things to different people. This is probably due to the fact that circular economy is a broad and heterogeneous concept that can be applied to many different fields and which covers a big number of activities, but still this confusion and inconsistency could be problematic and even result in the collapse of the concept (Kirchherr et al. 2017). In the framework of this study we decided to follow a very clear definition that sums up the most important aspects of circular economy, the one provided by Geissdoffer et al. (2017), who define Circular Economy as "a regenerative system in which resource input and waste, emission, and energy leakage are minimised by slowing, closing, and narrowing material and energy loops. This can be achieved through longlasting design, maintenance, repair, reuse, remanufacturing, refurbishing, and recycling”.

Circular economy aims at delinking economy from the linear model of production and consumption our society, since early industrialization, has always relied on (Ellen MacArthur Foundation 2013). The linear economy model is based on the 'take-make-dispose' pattern and it basically works as follows: companies extract raw materials and, with the use of energy, transform them into products, which are then sold to consumers, who will use them until they don't serve their purpose anymore and are finally discarded as waste. This consumption-based linear system is not sustainable, and it entails extensive losses of resources and value all along the value chain. During the entire $20^{\text {th }}$ century, linear economy's wasteful system was supported by the declining real prices of natural resources. Since obtaining new resources and materials as well as disposing of them was so cheap and easy, a conscious use and reuse of those materials was not considered as a priority or as something particularly necessary. However, things started to change with the beginning of the new century, when real prices of natural resources started to increase. Not only commodity prices increased, but also their price volatility augmented. Together, high and volatile commodity prices slowed down global business growth, and ultimately economic growth. This is making companies and business leaders realize that the linear model of production is risky and wasteful in terms of resources and costs, and as a consequence many of them are moving or are taking into consideration the idea of moving towards an alternative industrial model that can decouple revenues from material inputs, which is circular economy (Ellen MacArthur Foundation 2013). Differently from the linear model, circular economy promotes a system in which products are intentionally designed to be easily reused, recycled, disassembled and refurbished, with the understanding that it is the reuse of large amounts of material reclaimed from end-of-life products, rather than the extraction of resources, the basis of economic growth. In this context, the economic system relies much more on unlimited resources, like labour, rather than on finite natural resources, which instead, assume just a supporting role.

Circular economy is attracting so much attention among academics, industry and policymakers because it is expected to produce big benefits and gains on both economy, environment and society. It can be applied at any level of the economy: micro, meso and macro. It is important to make this specification in order to better understand the focus of this study. Let's now see what each one of these levels consists of.

- Micro level: at this stage, circular economy focuses on individual actors, especially companies (Zhu et al. 2010), which put in action different strategies and processes in order to improve circularity of their production, as for example, eco-design, cleaner production strategies, resource efficiency initiatives and labelling systems (Ghisellini et al. 2016).

- Meso level: at this level, circular economy focuses on actors interactions, particularly on inter-firm networks, that include, for instance, industrial symbiosis, eco-industrial parks and green supply-chain management. In these systems, industries that traditionally work separately, decide to engage in complex interplays of resource exchange (water, energy, materials and by-products), with the objective of obtaining economic and environmental benefits (Ghisellini et al. 2016). 


\section{INSIGHTS INTO REGIONAL DEVELOPMENT}

ISSN 2669-0195 (online) http://jssidoi.org/jesi/

2020 Volume 2 Number 3 (September)

http://doi.org/10.9770/IRD.2020.2.3(4)

- Macro level: finally, at this level, circular economy is considered from a national or global point of view, with an emphasis on legislation, environmental policy impact, zero waste regimes, recycling- oriented societies and so on (De Jesus et al. 2017).

This study mainly focuses on the meso level of circular economy. The Prato industrial cluster is, in fact, an ecoindustrial cluster that has implemented industrial symbiosis and other circular practices and strategies. However, before exploring these themes, it is necessary to introduce another equally important concept: eco-innovation. In the framework of this study, it is useful to previously introduce eco-innovation for two main reasons: a) ecoinnovation is a fundamental lever for the implementation of circular economy at any level; b) industrial symbiosis itself can be considered as an organizational and systemic eco-innovation.

\section{Eco-Innovation as a driver of circular economy in industrial clusters}

The term 'eco-innovation' gained momentum during the second half of the 1990s, in the wake of the debates preceding and following the 1992 Rio Earth Summit (Fussler and James 1996; Rennings 2000). The debate on eco-innovation has kept attracting increasing attention over the last decade, especially since eco-innovation has been explicitly recognized as a critical factor for meeting sustainable development goals (SDGs) (UN 2015). According to the report written by the Innovation for Sustainable Development Network (Inno4seeds.net 2019), eco-innovation, if largely diffused and effectively implemented, could help reaching at least 9 different SDGs ${ }^{\dagger}$ and could be beneficial for 3 additional SDGs in low- and middle-income countries $\$$. Several different definitions of eco-innovation have been produced up until now, we report as follows the one proposed by Kemp and Pearson (2007), which is one of the most widely accepted and recognized. According to them, "Eco-innovation is the production, assimilation or exploitation of a product, production process, service or management or business method that is novel to the organisation (developing or adopting it) and which results, throughout its life cycle, in a reduction of environmental risk, pollution and other negative impacts of resources use (including energy use) compared to relevant alternatives". As it can be noticed in the definition, eco-innovation is a very broad concept that covers many different areas. In fact, eco-innovations can be classified into several types. Usually, a main distinction is made between product, process and organizational eco-innovations:

- A product eco-innovation is a new or improved good or service that reduces environmental risk, pollution and negative impacts compared to the products previously produced or used by the organization. The innovative characteristics of a product eco-innovation can be linked to: lower resource content and reduced use of hazardous materials; lower levels of resources used during production or delivery; longer life; improved recyclability; reduced environmental impact linked to the use of the product.

- A process eco-innovation is a new or improved process that reduces environmental risk, pollution and negative impacts compared to the process technology previously used by the organization. The characteristics of an eco-innovative process can be linked to: lower levels of energy, material, water or other inputs used to produce or deliver one unit of product; lower air, water, soil or noise pollution due to the production or delivery of one unit of product; replacement of hazardous materials used during the processes.

- An organizational eco-innovation is a new or improved organizational method that contributes to the reduction of environmental risk, pollution and negative environmental impacts compared to the organizational methods previously used by the unit. The characteristics of organizational eco-innovation can include: new or improved ways and strategies to manage a reduction in the environmental impacts of

\footnotetext{
$\dagger$ industry, innovation and infrastructure (SDG 9), responsible consumption and production (SDG 12), good health and wellbeing (SDG 3), affordable and clean energy (SDG 7), sustainable cities and communities (SDG 11), climate action across the world (SDG 13), life below water (SDG 14), life on land (SDG 15), and partnerships for the goals (SDG 17).

$\$$ clean water and sanitation (SDG 6), zero hunger (SDG 2), and no poverty (SDG 1).
} 


\section{INSIGHTS INTO REGIONAL DEVELOPMENT}

ISSN 2669-0195 (online) http://jssidoi.org/jesi/

2020 Volume 2 Number 3 (September)

http://doi.org/10.9770/IRD.2020.2.3(4)

the unit's activities and operations; new or improved methods to reduce or better managing the amount of waste produced per unit; new or improved ways to increase operations energy efficiency.

According to the report written by the Inno4seed.net (2019), apart from this basic distinction, it can be possible to distinguish at least 4 additional kinds of eco-innovations:

- Marketing eco-innovations, which are new or improved marketing methods used to promote eco-friendly products. Stimulating the demand and the adoption of this kind of products, marketing eco-innovations can contribute to lower environmental impacts.

- Business model eco-innovations, which consist of "new business models that reshape the way users receive value based on lower environmental impacts of products (goods and services) and the way these products are produced and delivered" (Inno4seeds.net 2019). It needs to be said that sometimes different types of eco-innovations can overlap, so for example, a business model eco-innovation can also be an organisational innovation, which involves also processes and marketing eco-innovations.

- Systemic eco-innovation, which consists in a change or implementation of a system, with the objective of reducing the environmental impacts of the multiple actors involved in the system in a coordinated way, improving its overall environmental performance in a more comprehensive and efficient way than the individual actors would have been able to do.

- Social eco-innovations, that are new social arrangements aimed at reaching environmental benefits. These could result, for example, from a group of people that starts using fewer natural resources or that establishes and follows circular economy principles.

These eco-innovation categories are not mutually exclusive. An eco-innovation, for example, could include both a product and a process element or a business model eco-innovation could also be a systemic or a social ecoinnovation.

After having explored the different levels of circular economy and the different types of eco-innovation, it is time to investigate what are the links between eco-innovation and circular economy, and to understand how specific types of eco-innovation can have an impact on specific levels of circular economy. First of all, it needs to be said that eco-innovation aims at achieving not only environmental but also economic benefits (Ekins 2010). The novelty of eco-innovation lies, in fact, in its potential capability to lead to win-win situations, in which economic growth and enhanced environmental quality coexist. According to Popp et al. (2010), the decoupling between economic growth and environmental degradation, which is also one of the main objectives circular economy aims at achieving, depends heavily on technological improvements that can reduce pressure on the environment. Barbieri et al. (2016), instead, bring the concept even further than the simple conception of technological improvements. According to them "moving towards a circular economy involves a rethinking of production cycles, production technologies, consumer behaviour and environmental policies, which are all factors that hinge heavily on the concept of EI" (Barbieri et al. 2016). At this point, it is possible to intuitively understand that the two concepts of eco-innovation and circular economy are closely related, but their boundaries still appear a bit blurred, so that it's not an easy task to define this link. This is also due to the fact that this topic has not been taken much into account in academic literature. Increasing attention started to be devoted to the link between the two concepts with the EU Action Plan for the Circular Economy (European Commission 2015), as also with the EcoInnovation Action Plan (European Commission 2011). However, there are still just few studies considering the explicit importance of eco-innovation for a circular economy (Eco-Innovation Observatory 2016). One of the most comprehensive studies regarding this topic is the one by De Jesus et al. (2017), who performed a careful literature review and analysed over 140 peer-reviewed articles related to eco-innovation and circular economy. According to it, not every eco-innovation is linked to circular economy, and not all dimensions of circular economy require innovation, but there is no doubt that some overlapping do exist and that they are strictly bounded to each other. 


\section{INSIGHTS INTO REGIONAL DEVELOPMENT}

ISSN 2669-0195 (online) http://jssidoi.org/jesi/

2020 Volume 2 Number 3 (September)

http://doi.org/10.9770/IRD.2020.2.3(4)

For what concerns circular economy macro level, process and organizational eco-innovations seem to be the most emphasized and relevant ones for the actual realization and achievement of a circular economy. Moreover, technological eco-innovations appear to be particularly important, especially when they consist of incremental innovations that redesign already existing products and production methods, and when they are focused on increasing resource productivity (De Jesus et al. 2017).

For what concerns circular economy micro level, instead, the focus is on goods and services eco-innovations and partially also on process eco-innovations, which are aimed at increasing product durability, quality and efficiency, and at designing circular business models (De Jesus et al. 2017).

Finally, for what concerns circular economy meso level (the level this study is focused on and that consequently we will try to deepen the most), organizational or systemic eco-innovations appear to be particularly important for its realization and development, especially incremental ones aimed at increasing resource productivity and material reuse and recycling. Eco-innovations at meso levels are usually designed to exploit potential synergies within the value chain and the territory, or to enable new types of "green collective innovation", like sharing services or other strategies that can lead to a maximisation of the value of common resources (De Jesus et al. 2017). As previously explained, the meso level of circular economy mainly deals with networks and interactions, which are usually built in order to share materials and by-products, but also utilities and infrastructures, or to enhance cooperation in research and investments and to reduce costs. At the meso level, thus, eco-innovation is fundamental in order to build, develop and enhance these networks, such as industrial symbiosis, eco towns, urban symbiosis and so on. Industrial symbiosis, for example, is an eco-innovation which involves many different processes and activities and, as a consequence, is often considered and categorized as a different kind of ecoinnovation, depending on the author. Pigosso et al. (2018), for example, defined it as a systemic eco-innovation, while others as a business model eco-innovation (Inno4sd.net 2019). Anyway, as previously explained, ecoinnovation categories are not mutually exclusive, furthermore we believe the existence of different definitions or categorizations is not problematic.

Based on what we just said, industrial symbiosis can be considered as an eco-innovation that can help the implementation of circular economy at the meso level; but what is it in practical terms? One of the definitions that is most commonly cited and reported in academic literature is the one by Chertow (2000), according to whom industrial symbiosis is that part of industrial ecology that "engages traditionally separate industries in a collective approach to competitive advantage involving physical exchange of materials, energy, water and byproducts. The keys to industrial symbiosis are collaboration and the synergistic possibilities offered by geographic proximity". With the passing of time, the conception of industrial symbiosis evolved and extended also to other kind of networks, that did not require geographic proximity for example. Consequently, still using the definition by Chertow as a basis, many new definitions arose, as the one by Domenech at al. (2019), that defines industrial symbiosis as "a system approach to a more sustainable and integrated industrial system, which identifies business opportunities that leverage underutilised resources (such as materials, energy, water, capacity, expertise, assets etc)". Moreover, it needs to be said that industrial symbiosis doesn't involve just the exchange of by-products or materials, but also the sharing of services or infrastructures between all the actors involved (van Berkel et al. 2009; De Jesus et al. 2018). As a tool of circular economy, also industrial symbiosis aims at achieving environmental, economic and social benefits. Environmental gains are mainly generated by the reduction of waste, emissions, primary inputs and energy (Chertow 2000). Economic benefits mainly arise from the lower costs for waste disposal as also from lower purchase of raw resources (Albino et al. 2016). For what concerns social benefits instead, industrial symbiosis seems to have a positive impact on the generation of new jobs and the creation of new firms (Mirata 2004).

\section{Italian industrial clusters and their environmental impact}




\section{INSIGHTS INTO REGIONAL DEVELOPMENT}

ISSN 2669-0195 (online) http://jssidoi.org/jesi/

2020 Volume 2 Number 3 (September)

http://doi.org/10.9770/IRD.2020.2.3(4)

After deepening the concepts of circular economy and eco-innovation, we now address the notion of industrial clusters. The purpose of this section is to make clear why implementing circular economy at industrial clusters level can be so important and beneficial, especially in a country like Italy.

Firms agglomeration was for the first time described by Alfred Marshall in his famous work "Principles of Economics" (1890), chapter X of book IV, named "The Concentration of Specialized Industries in Particular Localities". Marshall defined these agglomerations as 'industrial districts' and theorized that they could lead to positive economic benefits for the firms included in the district, such as higher productivity, knowledge spillover, labour pooling, growth of subsidiary trades among the firms, hereditary skills and the presence of specialized suppliers (Marshall 1890; Belussi et al. 2008). Michael Porter revived the concept of firms agglomeration in the 1990s. He labelled them as 'clusters' and defined them as "geographic concentrations of interconnected companies and institutions in a particular field" (Porter 1998).

According to Becattini (2002), industrial clusters in Italy started to bloom after the second world war, during the "economic miracle" phase, which lead to higher incomes and better life conditions for a big share of the middle class. This, in turn, lead to new sets of needs and to higher demand for personalized and differentiated goods. These changing needs and desires had a detrimental impact on big factories that mainly produced standardized goods, and added to a) the incapacity of other countries to provide these kinds of goods and b) the vast presence of artisanal productive specialization that provided skilled workforce, lead to the emergence of smaller factories, which produced more differentiated goods and which tended to organize themselves in clusters. With the passing of time, industrial clusters kept developing and spreading on the entire national territory, until becoming one of the distinctive traits and, most importantly, one of the driving forces of Italian economy (Schillirò 2017). Italian production system is, in fact, characterized by a vast number of small and medium enterprises, mainly organized in clusters. According to ISTAT (2015), in 2011 they amounted to 141 units and they represented one-fourth of the Italian economic system, both for what concerns LMAs ${ }^{\S}(23.1 \%$ of the total), workers $(24.5 \%)$ and local units (24.4\%). Moreover, manufacturing employment of industrial clusters represents over one-third of overall employment in Italy.

However, while they represent a determinant driver of Italian economic development, they can also be considered as a driver of environmental degradation (Cariani 2010). According to the report "Ecodistretti 2009", environmental performances of industrial clusters got worse and worse in last years for what concerns both energy and water consumption as also waste production. Cariani (2010) reached these conclusions analysing sectorial data and aggregated data. However, it needs to be said that data regarding environmental externalities produced by industrial clusters are quite limited. This is mainly due to the fact that up until now research has been much more focused on the environmental impacts of industrial sectors, rather than on the impacts of industrial agglomeration (Montini and Zoboli 2004), even though it was clear since the beginning of industrial revolution that 'Marshallian' industrial districts were an important source of environmental degradation and damages, particularly for what concerns acidic air depositions and ecosystem alterations (Ponting 1991). Another problematic aspect of analysing environmental impact (pollution in particular) of industrial clusters is linked to the difficulties in distinguishing externalities generated by them and those generated by other local sources of pollution. In spite of all these problematics, some studies on the topic have been conducted anyway, as the one by Montini and Zoboli (2004), who tried to assess the impact of existing industrial clusters in Emilia Romagna, and whose results suggest that local industrial concentration has an important impact on local environmental pressures, especially for what concerns air pollutant emissions.

Even though industrial clusters represent a source of pollution and environmental degradation, they have the potential to become more sustainable and to reduce their impacts, thanks to their intrinsic characteristics. According to Cainelli at al. (2012), in fact, industrial clusters appear to be suitable environments in which to

\footnotetext{
$\S$ LMAs stands for labour market areas, which are geographical areas where the greatest part of the labour force lives and works.
} 


\section{INSIGHTS INTO REGIONAL DEVELOPMENT}

ISSN 2669-0195 (online) http://jssidoi.org/jesi/

2020 Volume 2 Number 3 (September)

http://doi.org/10.9770/IRD.2020.2.3(4)

introduce and implement eco-innovations -in particular systemic eco-innovations-, due to their intrinsic characteristics, and in the specific due to their:

a) Networking nature. Firms in industrial clusters are part of a network in which they cooperate and compete at the same time, and this has the potential to drive the adoption of innovations and eco-innovations. Networking appears to be essential in order to achieve more radical eco-innovations, that a firm alone, due for example to insufficient resources, would probably not being able to implement. Moreover, networking positively affects environmental-knowledge spillovers, and can also increase the efficiency of some innovation or eco-innovations implemented in clusters.

b) Geographical proximity. Knowledge spillovers and learn-by-interacting (both made possible by geographical proximity) appear to increase technological innovation of firms embedded in industrial clusters (Cainelli 2008). This seems to work also for eco-innovations, some studies found out that firms belonging to the same industrial cluster, due to complementarity effects, are more likely to influence each other and to innovate and pursue environmental innovation simultaneously (Mazzanti \& Zoboli 2008). Moreover, embeddedness of firms in environmental-friendly institutional set-ups seems to be a positive stimulus for implementation of eco-innovations (Mazzanti \& Zoboli 2009).

In the last decades, industrial clusters more attentive of environmental protection started to spread in Italy. They are known as "Ecologically Equipped Productive Area" ("Area Produttiva Ecologicamente Attrezzata" or APEA) and can be described as industrial areas provided with the necessary infrastructures and systems to ensure health and environmental protection (ISPRA 2014). They were formally introduced in 1998, with the Legislative Decree n. 115, article 26, which established that "the Regions should discipline, by means of their own laws, the industrial areas and the ecologically equipped areas, fitted out with the necessary infrastructures and systems suitable to guarantee the safeguarding of health, safety and the environment". The definition of APEA is quite broad and includes clusters that introduced measures to contain their environmental impact very different one from the other. For instance, Rete Cartesio, which is a network that periodically publishes reports about Italian eco-industrial clusters, the ranking of the best performing ones and the best practices they implemented, takes into account many different characteristics and parameters in order to identify and rank eco-industrial clusters (Rete Cartesio 2013), such as:

a) Presence and typology of environmental infrastructures aimed at reducing pollution, manage waste and energy and promote environmental innovation;

b) Diffusion of environmental technologies in the firms;

c) Increase in the number of firms with environmental certification;

d) Presence of eco-labels;

e) Realization of environmental monitoring programmes by public authorities;

f) Implementation of eco-innovation projects;

Eco-industrial clusters can implement many different kinds of eco-innovations within themselves, but not all of them are linked or are expected to produce circular systems or practices. It can be said that 'circular clusters' can be considered as APEAs and as eco-industrial clusters, but not every eco-industrial cluster can be considered as a circular one.

After having introduced the notions of industrial cluster and eco-industrial cluster, it's the moment to take into account specifically the textile ones and their environmental impacts. Textile and clothing sector in Italy has always been one of the most important ones and a fundamental driver of economic growth. Italian textile firms have been mainly focused on producing high-quality products, which lead Italian fashion industry to be renowned worldwide. One of the main factors that made it possible was textile industrial clusters, characterized by strong technical knowledge and a high differentiation and specialization, which represented their competitive advantage. 


\section{INSIGHTS INTO REGIONAL DEVELOPMENT}

ISSN 2669-0195 (online) http://jssidoi.org/jesi/

2020 Volume 2 Number 3 (September)

http://doi.org/10.9770/IRD.2020.2.3(4)

In 2011 industrial clusters specialized in textile and clothing sector were 32, which corresponded to $22 \%$ of total industrial clusters and which absorbed $26,1 \%$ of the total workforce employed by industrial clusters (ISTAT 2015). At this point, the relevance of textile sector and textile clusters for Italian economy is quite clear, but what about their environmental impact? Textile industry affects environment from many different points of view: resource consumption, water use and water pollution, energy use, chemical release, greenhouse gas emissions and waste production are just some of them.

a) Resource consumption. Textile sector is one of the most resource consuming ones. It relies heavily on both renewable, like natural fibres, and non-renewable resources, like oil used to produce synthetic fibres or chemicals used to dye and process textiles (Ellen MacArthur Foundation 2017). It has been estimated that in 2017, 675 million tonnes, which means $1,321 \mathrm{~kg}$ per person, of raw materials were used in order to produce clothing, footwear and household textiles purchased by all European households (ETC/WMGE 2019). This comprises every kind or resource, except for water, that we take into consideration separately afterwards.

b) Water consumption and pollution. Textile industry is well known for being a highly water intensive sector, in fact it requires large amounts of water for most of its operations, starting from the washing of fibres, till bleaching and dyeing of textiles and the washing of finished products. On average, 200-400 litres of water are necessary to produce $1 \mathrm{~kg}$ of finished product (Buscio et al. 2019). According to Toprak et al. (2017), the average water consumption of a medium textile firm is about 1,6 million litres per day. Moreover, textile industry's intensive use of water produces also huge amounts of polluted wastewater, whose components and pollution levels mainly depend on the processing and on the kind of fibre used (Buscio et al. 2019). Wastewater, in fact, can contain a wide variety of different chemicals and, if not properly treated before being released into the environment, it could cause big health and environmental damages.

c) Energy consumption. Textile industry is also very consuming from the energy point of view. Energy is used to heat, to dry, to make the machines work, to execute the different processes and of course this has an impact on its greenhouse gas emissions and on the sector's carbon footprint. Different types of energy are necessary in the textile sector, electricity is the main energy source, but also coal, and LPG are commonly used. They are usually incinerated to produce steam, releasing at the same time big shares of greenhouse gasses (Toprak et al. 2017).

d) Air emissions. According to the Ellen MacArthur Foundation (2017), greenhouse gas emissions generated by textile production amounted to 1.2 billion tonnes $\mathrm{CO} 2$-eq in 2015 , which just to give an idea corresponds to more than international flights and shipping emissions together. Gaseous emissions are considered to be the second biggest pollution problem due to textile industry (after effluent quality). It needs to be said that data regarding air emissions generated by textile industry are not easily available, but it is known that many different phases and processes release air emissions. Textile firms are likely to emit, among the others, dust, lint, acid vapor, solvent mists, oil fumes, boiler exhausts and odor (Toprak et al. 2017).

e) Solid waste generation. Solid waste produced by textile industry is mainly non-hazardous, such as scraps of fabric and yarn, packaging waste, dirt, waxes, cardboard reels and so on. However, to a smaller extent, textile industry also produces hazardous solid waste, such as sludge and dye and chemical tanks, since they contain toxic material.

At this point, after having summarized the numerous environmental impacts that are normally produced by textile industry, in next section it will be extensively analysed how textile industrial clusters can deal with them and substantially reduce them, as the Prato $1^{\text {st }}$ industrial Macrolotto was able to do, implementing circular economyrelated eco-innovations.

\section{Prato $1^{\text {st }}$ industrial Macrolotto case study}

Prato textile industrial cluster is one of the biggest industrial clusters in Italy, the largest textile site in Europe and among the most important ones of the world, mainly for what concerns production of woolen yarns and fabrics. It 


\section{INSIGHTS INTO REGIONAL DEVELOPMENT}

ISSN 2669-0195 (online) http://jssidoi.org/jesi/

2020 Volume 2 Number 3 (September)

http://doi.org/10.9770/IRD.2020.2.3(4)

comprises about 7200 firms specialized in the fashion sector -among which 2000 specialized specifically in the textile sector strictu sensu- that employ about 35,000 workers, and which produce 17\% of overall Italian textile exports (Barberis et al. 2018). Prato industrial cluster comprises three different 'Macrolotti': Macrolotto 0, Macrolotto 1 and Macrolotto 2. A macrolotto can be defined as a subdivision of the territory that can be done for different purposes, in this case productive ones. Each one of them has different characteristics and is managed by different management bodies. The focus of our study is specifically on the 1st industrial Macrolotto, which hosts about 700 small and micro firms and employs about 3000/4000 workers**. It was the first productive area in Italy to engage in voluntary and continuative environmental improvement programmes, in order to implement the legislative decree n. 112/1998. The decree also establishes that each APEA needs to have a unique management body that has different functions and responsibilities, among which the one of ensuring the engagement of the cluster in sustainable activities and environmental-friendly programmes. In the case of the $1^{\text {st }}$ industrial Macrolotto, the unique management body is constituted by CONSER, whose partners are all the owners of the buildings present on the industrial area and whose functions are to safeguard and promote services and infrastructures investments in the area, to coordinate and maintain relationships between CONSER members and local authorities, as also to properly manage and maintain the industrial aqueduct and the centralized implant of wastewater recycle. CONSER and its $1^{\text {st }}$ industrial Macrolotto was not only the first one to engage into environmental and social sustainability practices, but according to the ranking by Rete Cartesio (2013), also the best performing Italian Eco-industrial cluster. CONSER introduced in the Prato $1^{\text {st }}$ industrial Macrolotto different practices of different nature. Let's analyse them more in depth:

Water. Water management is probably the most important sphere of this analysis, due to the heavy impact textile industry usually has on consumption and pollution of water, and in spite of that to the amazing results $1^{\text {st }}$ industrial Macrolotto has been able to reach. Prato $1^{\text {st }}$ industrial Macrolotto was, in fact, the first industrial cluster in Italy to equip itself since 1990 with a centralised water recycling plant, with annexed an industrial aqueduct and a firefighting system (Cariani 2013). The main idea of this closed system was to purify wastewater already utilised by industries and citizens from Prato, for then being reused within the district for industrial processes, productive activities, cooling towers, firefighting systems and sanitary facilities (CONSER 2009). At the beginning, in 1990, the system was able to produce 1.750 .000 cubic meters per years of recycled water, but after different improvements, in 2005, it was able to produce an amount of 5.000.000 cubic meters per year (CONSER 2009). The main reasons for implementing this system are linked to the preservation of the water table that also represents the main water source for all citizens living in Prato, since it is clear that using water for drinking purposes is more important than using it for industrial ones. Moreover, it is crucial also to preserve water for future generations. It is estimated that this system will allow to save for future generations an amount of water that corresponds to the drinking needs of 100.000 citizens a year (Cariani 2013). On their side, instead, firms located in the cluster will never lack their water supply. It is clear that the costs borne for production and distribution of recycled water are higher than the ones the cluster would borne if it used table water, due to costs for employees, chemicals, energy and so on. Thus, in order to make the use of recycled water competitive, CONSER between 1996 and 1999 collaborated with the Italian Environmental Ministry, providing its unique experience, to the formulation of the legislative decree 152/1999 article 26, which incentivizes the use of recycled water and at the same time disincentivizes the use of primary water, through the use of a tax on water purification, higher for polluters of primary waters, lower for polluters of recycled water. With the implementation of this law, firms working in the Prato industrial cluster and using recycled water were able to save a cumulative amount of 300.000 euros per year (CONSER 2009). Burdens of this incentive, instead, fall on firms that keep using primary water. This water recycling system had so much success and has been so widely recognized as a revolutionary project that the Municipality of Prato in 2016 was chosen as the Italian representative for the EU "Urban Agenda: Circular Economy Partnership" initiative, a project aimed at enhancing the EU understanding of specific problems

\footnotetext{
** The information source is CONSER official site: http://www.conseronline.it/?page $\mathrm{id}=122$
} 


\section{INSIGHTS INTO REGIONAL DEVELOPMENT}

ISSN 2669-0195 (online) http://jssidoi.org/jesi/

2020 Volume 2 Number 3 (September)

http://doi.org/10.9770/IRD.2020.2.3(4)

and sharing best practices among member states. In this context, Prato leads the debates regarding wastewater reuse (Barberis 2018).

Energy. CONSER main objectives regarding energy are to promote the use of clean energy, the reduction of energy costs for the firms of the cluster and the realization of centralized or distributed energy systems. The most significative and durable initiative in this field that CONSER promoted was a convention with a local bank that would allow firms to implement photovoltaic systems, being entirely funded by the bank. While the funds had to be returned in 10 years maximum, at the same time, firms could use since day one all the energy produced by their solar power systems. The convention was stipulated in 2010, and in 2012 already more than 20 hectares of photovoltaic systems were built on firm's roofs. These solar power systems reduced firms' energy costs of an aggregated amount of over 4,5 million euros per year and avoided the release in the atmosphere of over 16.000 tonnes of CO2 per year (Cariani 2013).

Services and facilities. In this section, different practices implemented in different fields will be discussed. CONSER not only tried to address environmental problems, but also social ones. Safety has always been a crucial aspect for CONSER, in fact, even though a specific law about safety procedures into productive areas did not exist yet, it decided to introduce some innovative measures in order to secure the entire area of the $1^{\text {st }}$ industrial Macrolotto, among which:

- Firefighting aqueduct fuelled by recycled water, planned in order to operate as a centralised firefighting system covering the entire area of the $1^{\text {st }}$ industrial Macrolotto. The objective was not only to secure the entire area, but also to eliminate the costs associated with the previously existing 380 firefighting systems present in single firms.

- Centralised parking lots in the busiest areas of the cluster in order to reduce potential road accidents. Safety-related services are not the only ones provided by CONSER. It also implemented different kinds of other measures aimed at improving workers' quality of life, such as:

- An inter-company kindergarten, available for employees of all the firms working in the cluster at reduced tuition fees.

- Centralised laundry, pharmacy, post and grocery services, directly delivering the different products and services to workers houses, all of them with reduced prices for the employees.

Objective of these services is not only to facilitate workers of the firms operating in the cluster by reducing their expenses and time lost travelling, but also to contain pollution and the overall environmental impact of the working area by reducing traffic and transportation. Moreover, one last project implemented by CONSER, which unfortunately did not succeed but the consortium would like to reproduce, is linked to shared and sustainable mobility. CONSER, together with the Municipality of Prato -which provided some electric minibuses for free to the $1^{\text {st }}$ Macrolotto- introduced a free car-pooling and car sharing service available for all firms operating in the cluster. This service was introduced in order to reduce pollution due to transportation of people and goods and associated costs. The results obtained showed that the service had an actual impact on reducing the use of traditional means of transport and on reducing CO2 emissions (CONSER 2009).

On the basis of what it has been explained in this last section, can we actually affirm that the different actions and practices introduced by CONSER in Prato $1^{\text {st }}$ industrial Macrolotto can be considered as circular economy-related eco-innovations? In order to answer this question, some definitions we gave in previous sections should be briefly retaken. To describe industrial symbiosis we used the definition provided by Domenech et al. (2019), according to whom industrial symbiosis is "a system approach to a more sustainable and integrated industrial system, which identifies business opportunities that leverage underutilised resources (such as materials, energy, water, capacity, expertise, assets etc)". Then we added some specifics, as that it doesn't involve just exchange of by-products and materials, but also sharing of services or infrastructures between all actors involved (van Berkel et al. 2009; De Jesus et al. 2019). In accordance with the above description, it can be said that: the centralised water recycling 


\section{INSIGHTS INTO REGIONAL DEVELOPMENT}

ISSN 2669-0195 (online) http://jssidoi.org/jesi/

2020 Volume 2 Number 3 (September)

http://doi.org/10.9770/IRD.2020.2.3(4)

system and the firefighting aqueduct fuelled by recycled water, as also the inter-company kindergarten, the centralised laundry, pharmacy, post and grocery services, the centralised parking and the car-pooling and carsharing services implemented in the $1^{\text {st }}$ industrial Macrolotto can be all considered as real-life applications of the broad concept of industrial symbiosis, which in turn can be considered as "an eco-innovation that help the implementation of circular economy at the meso level". For what concerns, instead, the implementation of photovoltaic systems in the district, they cannot be considered as an application of industrial symbiosis nor an eco-innovation that can spur circular economy. However, they can be considered as important eco-innovations that can increase firms and the overall industrial cluster sustainability.

\section{Conclusions}

The paper aims at exploring how industrial clusters can become more circular through the implementation of ecoinnovations and, in the specific, which kinds of eco-innovations can spur circular economy at the level of industrial clusters, as also if industrial clusters can be considered suitable environments for the implementation of circular economy. The paper aims at answering these questions from both a theoretical and a practical point of view, thus performing an analysis about previous literature regarding the topic, as also exploring a real-life case study of an industrial cluster which was actually able to implement circular economy-related eco-innovations and at the same time thriving and obtaining optimal environmental outcomes.

First of all, the paper starts clarifying the concept of circular economy and investigating how it can be implemented at any level of economy, both micro, meso and macro. Our focus, however, is specifically on the meso level, since it deals with inter-firms networks, actors interactions and eco-industrial clusters. At this point the question is which kind of eco-innovations could actually spur meso-level circular economy. The third section starts exploring the concept of eco-innovations and all the different types of eco-innovations, which can be categorized as: products, processes, organizational, systemic, social, business model and marketing ecoinnovations. Critically analysing previous studies regarding the concept, it has been seen that eco-innovations that can spur meso level circular economy are mainly organizational or systemic ones. They are usually designed to exploit potential synergies within the value chain and the territory, or to enable new types of "green collective innovation", like sharing services or other strategies that can lead to a maximisation of the value of common resources. At the meso level, eco-innovation is fundamental in order to build, develop and enhance these networks, such as, industrial symbiosis, which is also one of the most famous and recognized examples. Consequently, we defined Industrial symbiosis as an eco-innovation that can help the implementation of circular economy at the meso level. In the next section we took into account specifically the context of italian industrial clusters, which are particularly important for Italian economic growth, but at the same time, also exert a considering impact on the environment, especially textile industrial clusters which are very wasteful in terms of resources, water in particular.

The purpose was to study the case study of the Prato industrial cluster, specifically the $1^{\text {st }}$ industrial Macrolotto, that even though is specialized in textile production, is considered one the best eco-industrial clusters in Italy. We explored which kinds of sustainable techniques and practices it implemented: the centralised water recycling system and the firefighting aqueduct fuelled by recycled water, the inter-company kindergarten, the centralised laundry, pharmacy, post and grocery services, the centralised parking and the car-pooling and car-sharing services. According to us they can all be categorized as real-life applications of industrial symbiosis. In fact, comparing these practices and the description of the systemic eco-innovations that can lead to circular economy at the meso level, including the definition of industrial symbiosis, we can see they match. This seems to confirm that circular economy in industrial clusters can be spurred by systemic eco-innovations.

At this point, it is possible to answer also the second question regarding the suitability of industrial clusters as environments in which to implement circular economy practices. Cainelli at al. (2012) suggested that industrial 


\section{INSIGHTS INTO REGIONAL DEVELOPMENT}

ISSN 2669-0195 (online) http://jssidoi.org/jesi/

2020 Volume 2 Number 3 (September)

http://doi.org/10.9770/IRD.2020.2.3(4)

clusters are suitable environments in which to introduce and implement eco-innovations, in particular systemic eco-innovations, due to their networking nature and their geographical proximity. Since, according to our studies, systemic eco-innovation in industrial clusters are likely to spur circular economy, we believe it is possible to take this theory even further, suggesting that industrial clusters, given their nature and characteristics, such as geographical proximity and networking nature, seem to be suitable environments in which to implement and maintain a circular economy. This can be particularly important especially in a country like Italy, whose economy heavily relies on industrial clusters. In fact, a general shift of Italian industrial clusters from linear to circular economy could lead to great results in terms of environmental impacts, as also in terms of economic and social impacts. However, further studies are necessary in order to assess the actual impact that the implementation of circular economy practices and eco-innovations in other industrial clusters could have on environment, society and economy.

\section{References}

Albino, B.; Fraccascia, L.; Magno, M. 2016. Business models for industrial symbiosis: A guide for firms. Procedia Environmental Science, Engineering and Management, 3, 83-93.

Barberis, V.; Borsacchi, L.; Pinelli, P. 2018. Circular economy and industrial symbiosis: The role of the municipality of Prato within the EU Urban Agenda partnership. The 24 $4^{\text {th }}$ ISDRS Conference "Action for a sustainable world: from theory to practice". June 13-15 2018, Messina, Italy.

Barbieri, N.; Ghisetti, C.; Gilli, M.; Marin, G.; Nicolli, F. 2016. A survey of the literature on environmental innovation based on main path analysis. Journal of Economic Surveys, 30(3), 596-623. https://doi.org/10.1111/joes.12149

Becattini, G. 2002. From Marshall's to the Italian "Industrial Districts". A Brief Critical Reconstruction. Complexity and industrial clusters. Physica-Verlag HD, pp. 83-106. https://doi.org/10.1007/978-3-642-50007-7_6

Belussi, F.; Caldaro, K. 2008. At the origin of the industrial district: Alfred Marshall and the Cambridge school. Cambridge Journal of Economics, 33(2), 335-355. https://doi.org/10.1093/cje/ben041

Buscio, V.; López-Grimau, V.; Álvarez, M.D.; Gutiérrez-Bouzán, C. 2019. Reducing the environmental impact of textile industry by reusing residual salts and water: ECUVal system. Chemical Engineering Journal, 373, 161-170. https://doi.org/10.1016/j.cej.2019.04.146

Cainelli, G. 2008. Spatial agglomeration, technological innovations, and firm productivity: Evidence from Italian industrial districts. Growth and Change, 39(3), 414-435. https://doi.org/10.1111/j.1468-2257.2008.00432.x

Cainelli, G.; Mazzanti, M.; Montresor, S. 2012. Environmental Innovations, Local Networks and Internationalization. Industry and Innovation, 19(8), 697-734. https://doi.org/10.1080/13662716.2012.739782

Cariani, R. 2009. Ecodistretti 2009. Made "Green" in Italy: le politiche ambientali dei sistemi produttivi locali e dei distretti industriali. Milano: FrancoAngeli.

Cariani, R. 2013. Eco-aree produttive, Guida all'eco-innovazione, alle politiche per la sostenibilità e ai progetti operativi nelle Aree Produttive Ecologicamente Attrezzate (APEA). Milano: Edizioni Ambiente.

Chertow, M.R. 2000. Industrial symbiosis: Literature and Taxonomy. Annual review of energy and the environment, 25(1), 313-337. https://doi.org/10.1146/annurev.energy.25.1.313

CONSER 2009. Rapporto ambientale e sociale anno 2009. http://www.arpat.toscana.it/notizie/arpatnews/2010/allegati/086-Conser-rappambsoc.pdf 


\section{INSIGHTS INTO REGIONAL DEVELOPMENT}

ISSN 2669-0195 (online) http://jssidoi.org/jesi/

2020 Volume 2 Number 3 (September)

http://doi.org/10.9770/IRD.2020.2.3(4)

De Jesus, A.; Antunes, P.; Santos, R.; Mendonça, S. 2017. Eco-innovation in the transition to a circular economy: An analytical literature review. Journal of cleaner Production, 172, 2999-3018. https://doi.org/10.1016/j.jclepro.2017.11.111

De Jesus, A.; Mendonça, S. 2018. Lost in Transition? Drivers and Barriers in the Eco-innovation Road to the Circular Economy. Ecological economics, 145, 75-89. https://doi.org/10.1016/j.ecolecon.2017.08.001

Domenech, T.; Bleischwitz, R.; Doranova, A.; Panayotopoulos, D.; Roman, L. 2019. Mapping Industrial Symbiosis Development In Europe - typologies of networks, characteristics, performance and contribution to the Circular Economy. Resources, Conservation and Recycling, 141, 76-98. https://doi.org/10.1016/j.resconrec.2018.09.016

European Commission 2011. Innovation for a Sustainable Future - the Eco-innovation Action Plan. https://eur-lex.europa.eu/legalcontent/EN/ALL/?uri=CELEX:52011DC0899

European Commission 2015. Closing the Loop - an EU Action Plan for the Circular Economy. https://eur-lex.europa.eu/legalcontent/EN/TXT/?uri=CELEX:52015DC0614

Eco-Innovation Observatory 2016. Eco-innovate! A guide to eco-innovation for SMEs and business coaches. $2^{\text {nd }}$ edition. https://www.ecoinnovation.eu/index.php/guide-for-smes

Ekins, P. 2010. Eco-innovation for environmental sustainability: concepts, progress and policies. International Economics and Economic Policy, 7(2-3), 267-290. https://doi.org/10.1007/s10368-010-0162-z

Ellen MacArthur Foundation 2013. Towards the Circular Economy. Economic and business rationale for an accelerated transition. https://www.ellenmacarthurfoundation.org/assets/downloads/publications/Ellen-MacArthur-Foundation-Towards-the-Circular-Economyvol.1.pdf

Ellen MacArthur Foundation 2017. Circular Fashion - A New Textiles Economy: Redesigning fashion's future. https://www.ellenmacarthurfoundation.org/assets/downloads/publications/A-New-Textiles-Economy_Full-Report.pdf

ETC/WMGE 2019. Textiles and the environment in a circular economy. https://www.eionet.europa.eu/etcs/etc-wmge/products/etcreports/textiles-and-the-environment-in-a-circular-economy

Fussler, C. and James, P. 1996. Driving eco-innovation: A breakthrough discipline for innovation and sustainability. London: Pitman. Geissdoerfer, M.; Bocken, N.; Savaget, P.; Hultink, E. 2017. The Circular Economy - a new sustainability paradigm? Journal of cleaner production, 143, 757-768. https://doi.org/10.1016/j.jclepro.2016.12.048

Ghisellini, P.; Cialani, C.; Ulgiati, S. 2016. A review on circular economy: The expected transition to a balanced interplay of environmental and economic systems. Journal of Cleaner production, 114, 11-32. https://doi.org/10.1016/j.jclepro.2015.09.007

Inno4seeds.net 2019. Maastricht Manual on Measuring Eco-innovation for a Green Economy. https://www.inno4sd.net/uploads/originals/1/inno4sd-pub-mgd-02-2019-fnl-maastrich-manual-ecoinnovation.pdf

ISPRA 2014. Indagine conoscitiva sull'applicazione di EMAS nei Distretti Italiani. http://www.isprambiente.gov.it/it/pubblicazioni/rapporti/R_192_14_Indagine_conoscitiva_sullattuazione_di_EMAS_new2.pdf

ISTAT 2015. $9^{\circ}$ Censimento dell'industria e dei servizi e Censimento delle istituzioni non profit. I distretti industriali 2011. https://www.istat.it/it/files/2015/10/I-distretti-industriali-2011.pdf

Marshall, A. 1890. Principles Of Economics. London: Macmillan.

Mazzanti, M.; Zoboli, R. 2008. Complementarities, firm strategies and environmental innovation: empirical evidence for a district-based manufacturing system. Environmental sciences, 5(1), 17-40. https://doi.org/10.1080/15693430701859638

Mazzanti, M.; Zoboli, R. 2009. Embedding environmental innovation in local production systems: SME strategies, networking and industrial relations. International Review of Applied Economics, 23(2), 169-195. https://doi.org/10.1080/02692170802700500

McKinsey\&Company 2016. The circular economy: Moving from theory to practice. https://www.mckinsey.com/businessfunctions/sustainability/our-insights/the-circular-economy-moving-from-theory-to-practice 


\section{INSIGHTS INTO REGIONAL DEVELOPMENT}

ISSN 2669-0195 (online) http://jssidoi.org/jesi/

2020 Volume 2 Number 3 (September)

http://doi.org/10.9770/IRD.2020.2.3(4)

Mirata, M. 2004. Experiences from early stages of a national industrial symbiosis programme in the UK: determinants and coordination challenges. Journal of Cleaner Production, 12(8-10), 967-983. https://doi.org/10.1016/j.jclepro.2004.02.031

Montini, A.; Zoboli, R. 2004. Environmental impact and innovation in industrial districts. The evolution of industrial districts. Physica, Heidelberg, pp. 272-315. https://doi.org/10.1007/978-3-7908-2700-2_13

Pigosso, D.C.A.; Andersen, M.; Schmiegelow, A. 2018. Measuring the Readiness of SMEs for Eco-Innovation and Industrial Symbiosis: Development of a Screening Tool. Sustainability, 10(8), 2861. https://doi.org/10.3390/su10082861

Ponting, C. 1991. A Green History of the World: The Environment and the Collapse of Great Civilizations. New York: Penguin books.

Popp, D.; Newell, R.; Jaffe, A. 2010. Energy, the environment, and technological change. Handbook of the Economics of Innovation. Vol 2, pp. 873-937. https://doi.org/10.1016/S0169-7218(10)02005-8

Porter, M. E. 1998. Clusters and the New Economics of Competition. Boston: Harvard Business Review. Vol. 76, No. 6, pp. 77-90. https://hbr.org/1998/11/clusters-and-the-new-economics-of-competition

Rennings, K. 2000. Redefining innovation. Eco-innovation research and the contribution from ecological economics. Ecological economics, 32(2), 319-332. https://doi.org/10.1016/S0921-8009(99)00112-3

Rete Cartesio 2013. Ecodistretti 2012, politiche ambientali dei distretti e cluster nazionali verso il Made Green in Italy. http://docplayer.it/19079595-Ecodistretti-2012-politiche-ambientali-dei-distretti-e-cluster-nazionali-verso-il-made-green-in-italy.html

Kemp R., Pearson P., 2007. Final report MEI project about measuring eco-innovation. https://www.oecd.org/env/consumptioninnovation/43960830.pdf

Kirchherr, J.; Reike, D.; Hekkert, M. 2017. Conceptualizing the circular economy: An analysis of 114 definitions. Resources, conservation and recycling, 127, 221-232. https://doi.org/10.1016/j.resconrec.2017.09.005

Schilirò, D. 2017. Italian Industrial Districts: Theories, Profiles and Competitiveness. Management and Organizational Studies, 4, 1-11. https://doi.org/10.5430/mos.v4n4p1

Toprak, T.; Anis, P. 2017. Textile industry's environmental effects and approaching cleaner production and sustainability, an overview. Journal of Textile Engeneering and Fashion Technology, 2(4), 429-442. https://doi.org/10.15406/jteft.2017.02.00066

UN 2015. Transforming our world: The 2030 agenda for sustainable development. https://www.unfpa.org/resources/transforming-ourworld-2030-agenda-sustainable-development

van Berkel, R.; Fujita, T.; Hashimoto, S.; Geng, Y. 2009. Industrial and urban symbiosis in Japan: analysis of the Eco-Town Program 1997-2006. Journal of Environmental Management, 90(3), 1544-1556. https://doi.org/10.1016/j.jenvman.2008.11.010

Zhu, Q.; Geng, Y.; Lai, K. 2010. Circular economy practices among Chinese manufacturers varying in environmental-oriented supply chain cooperation and the performance implications. Journal of Environmental Management, 91(6), 1324-1331. https://doi.org/10.1016/j.jenvman.2010.02.013

Francesca MAZZONI holds a Master Degree in Green Economy and Sustainability from the University of Ferrara and a Bachelor Degree in International Development and Cooperation from the University of Bologna. Her current research interests revolve around the broad concepts of Circular Economy and Sustainability.

ORCID ID: $\underline{\text { https://orcid.org/0000-0001-9902-8326 }}$ 
INSIGHTS INTO REGIONAL DEVELOPMENT

ISSN 2669-0195 (online) http://jssidoi.org/jesi/

2020 Volume 2 Number 3 (September)

http://doi.org/10.9770/IRD.2020.2.3(4)

\section{Acknowledgement}

The publishing was supported by Entrepreneurship and Sustainability Center, Lithuania

Make your research more visible, join the Twitter account of INSIGHTS INTO REGIONAL DEVELOPMENT:

@ IntoInsights

Copyright (C) 2020 by author(s) and VsI Entrepreneurship and Sustainability Center

This work is licensed under the Creative Commons Attribution International License (CC BY).

http://creativecommons.org/licenses/by/4.0/

cc) (i) Open Access 